\title{
LIST OF TABLES, CHARTS AND FIGURE
}

\section{Tables}

I. Paid Workers Classified by Industry, $1963 \quad \ldots \quad$ io

2. Growth in Membership of Employees' Trade Unions, 1937-1967

.. 16

3. Membership Strength of Trade Unions : Percent of Unions Classified by Size of Membership

.. 20

4. Membership Strength of Trade Unions : Number of Unions Classified by Size of Membership

.. $2 \mathrm{I}$

5. Average Annual Incidence of Strikes, 1946-1965 $\quad . \quad 33$

6. Average Duration of Strikes : Man-Days Lost Per Worker Involved

.. 34

7. Average Number of Workers Involved Per Strike $\quad \ldots \quad 35$

8. Causes of Strikes $\quad \ldots \quad 3^{8}$

9. Party Performance in Parliamentary Elections, $1947^{-1965} \quad \ldots \quad 57$

Charts

I. "Outsiders" and "Insiders" in Leadership Positions of Major Labor Organizations

2. Comparison of Membership in the Pre-1 965 Joint Committee of Trade Union Organizations and Post-1965 Labor Groupings

Figure

I. Growth in Membership of Employees' Trade Unions 
